\title{
Races of Hemileia vastatrix and Variation in Pathogenicity of Colletotrichum kahawae Isolates to Compact Coffee Genotypes in Tanzania
}

\author{
Deusdedit L. Kilambo ${ }^{1}$, Shazia O. W. M. Reuben ${ }^{2} \&$ Delphina Mamiro² \\ ${ }^{1}$ Tanzania Coffee Research Institute (TaCRI), Lyamungu, Moshi, Tanzania \\ ${ }^{2}$ Department of Crop Science and Production, Sokoine University of Agriculture, Morogoro, Tanzania \\ Correspondence: Deusdedit L. Kilambo, Tanzania Coffee Research Institute (TaCRI), Lyamungu, Moshi, \\ Tanzania. E-mail: dkilambo@gmail.com
}

Received: January 28, 2013 Accepted: May 17, 2013 Online Published: May 30, 2013

doi:10.5539/jps.v2n2p95

URL: http://dx.doi.org/10.5539/jps.v2n2p95

\begin{abstract}
Eighteen clones of coffee rust differentials were used to characterize rust races prevailing in the coffee growing areas in Arusha, Kilimanjaro, Mara, Bukoba, Kigoma, Mbeya and Ruvuma regions. The results showed the presence of seven new Hemileia vastatrix races causative agent for coffee leaf rust (CLR) in the surveyed coffee growing areas. The races were: XLI (v2, 5, 8), XLII (v2, 5, 7, 8 or v2, 5, 7, 8, 9), XV (v4, 5), XXX (v5, 8), XXXIII (v5, 7 or v5, 7, 9), XXXIV (v2, 5, 7 or v2, 5, 7, 9), XXXIX (v2, 4, 5, 6, 7, 8, 9). Four strains of Colletotrichum kahawae originating from 4 coffee ecosystems were used to test their level of pathogenicity on 16 compact coffee genotypes, Ctr088 and commercial variety N39. The four C. kahawae strains were less pathogenic to six compact coffee genotypes; CVT2, CVT4, CVT5, CVT7, CVT8 and CVT13, completely nil pathogenic to $\mathrm{Ctr} 088$, but significantly highly $(\mathrm{P}<0.05)$ pathogenic to $\mathrm{N} 39$. Coffee genotype Ctr088 was confirmed to be a potential donor of developing coffee berry disease (CBD) varieties with durable resistance. Differential interaction between the compact genotypes and the four C. kahawae strains needs further investigation.
\end{abstract}

Keywords: Races $H$. vastatrix, pathogenicity $C$. kahawae, compact coffee genotypes

\section{Introduction}

Coffee berry disease (CBD) caused by Colletotrichum kahawae Waller and Bridge sp. nov. (Waller et al., 1993), and coffee leaf rust disease caused by Hemileia vastatrix Berk et Br., causal agent of orange rust on coffee plants are the main cause of yield loss of Arabica coffee in Tanzania. Colletotrichum kahawae isolates from coffee plants including the one causing CBD were previously referred to as Colletotrichum coffeanum Noack, but recently it was recognized that there is a clear distinction between pathogenic form named as Colletotrichum kahawae Waller and Bridge Sp. Nov., and saprophytic form (Waller et al., 1993). However, there are pathogenic variations within C. kahawae strains. Studies by Rodrigues Jr. et al. (1992) found out that C. kahawae strains from Angola and Malawi exhibited slightly higher level of virulence than Kenyan strains. Similarly difference in the level of pathogenicity was found among C. kahawae strains in Tanzania (Kilambo et al., 2008). In the same study, C. kahawae strain from Cameroon was found to have higher level of pathogenicity than those from Tanzania, Kenya and Zimbabwe. Inspite of the differences in aggressiveness of C. kahawae strains, differential interactions between host and pathogen were seldom quantified (Kilambo et al., 2008; van der Graaf, 1981). There is therefore a need to update the characteristics of existing C. kahawae isolates established from coffee growing areas in order to obtain detail information on the variability of the CBD pathogen in Tanzania.

Worldwide, there are around 40 known physiological races of $H$. vastatrix causative agent for coffee leaf rust (CLR); of which seven were recorded to exist in Tanzania (Rodrigues Jr. et al., 1975). These were races I, II, III, XVII, XXIV, XI and XX. Coffee rust disease surveys carried out from 2006 to 2007 recorded new rust pathogen races XXII and XXXIV (CIFC, 2007). Two years later, five new coffee leaf rust pathogen races were recorded (TaCRI, 2009). These were races XXIII, XXIV, XXV, XXVIII and XXXI. Due to this observation a need to update information of coffee leaf rust pathogen races in coffee growing areas is important. Therefore, according to Flor (1971) varieties used for the identification of coffee leaf rust pathogen races called differential coffee leaf 
rust pathogen races were used to study the current pathogen variation in Tanzania.

The objective of this study was to characterize races of Hemileia vastatrix and variation in pathogenicity of Colletotrichum kahawae strains in the key coffee growing areas of Tanzania.

\section{Materials and Methods}

\subsection{Description of the Study Area}

Coffee leaf samples infected with Hemileia vastatrix and Colletotrichum kahawae isolates were collected from the sites as shown in Table 1. The study areas are marked with red dot (Figure 1).

Table 1. Sites for inoculum collection of Hemileia vastatrix and Colletotrichum kahawae

\begin{tabular}{llll}
\hline District & Site & Altitude (m. a.s.l.) & Status \\
\hline Hai & TaCRI Lyamungu & 1269 & On-station \\
Mbozi & Mbimba & 1605 & On-station \\
Mbinga & TaCRI Ugano & 1562 & On-station \\
Kasulu & Mwayaya & 1530 & On-station \\
Hai & Ng'uni & 1600 & On-farm \\
Hai & APK & 1100 & On-farm \\
Rombo & Mokala & 1500 & On-farm \\
Mbozi & Khanji Coffee Estate & 1620 & On-farm \\
Mbinga & Utiri & 1300 & On-farm \\
\hline
\end{tabular}
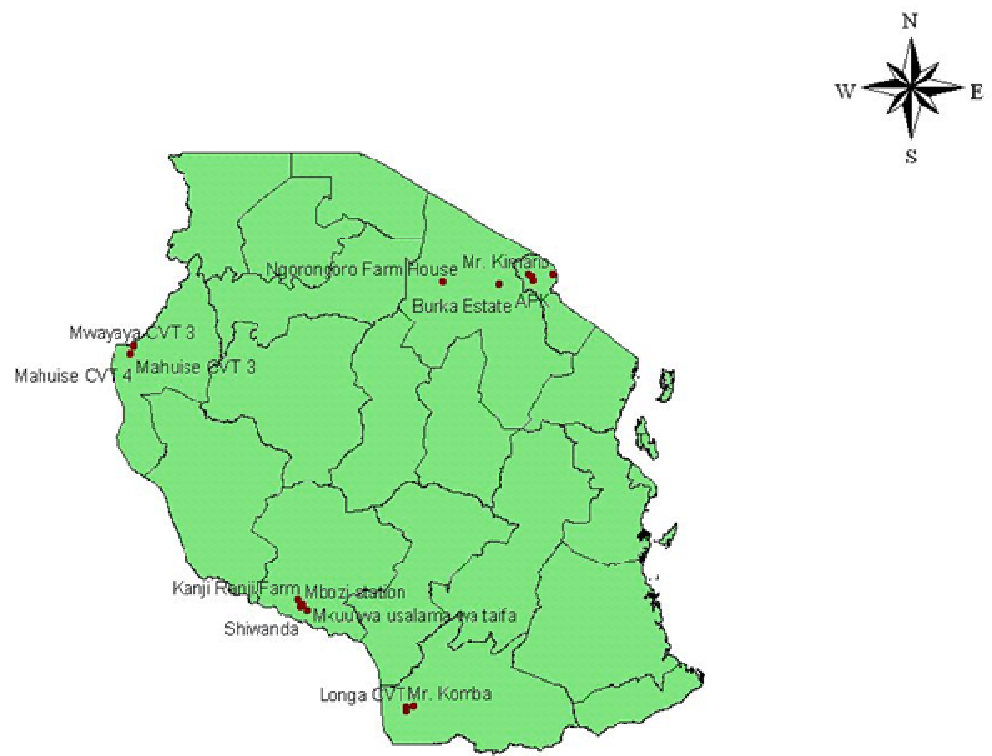

Figure 1. Map of Tanzania showing locations of on-station and on-farm fields marked with red dots

\subsection{Coffee Rust Disease Differentials}

Eighteen clones of Coffea spp. differential hosts for physiological races of Hemileia vastatrix were used. These clones were originally obtained by vegetative propagation from the original collection of coffee leaf rust disease centre at Oeiras Portugal (CIFC) (Table 2). The 18 clones of Coffea spp. involves: Coffea arabica, Coffea canephora, Coffea excels, Coffea racemosa and Coffea congensis. This could assist in distinguishing reaction of the races of the CLR pathogen Hemileia vastatrix which is so far found in coffee growing regions in Tanzania. Another form of coffee rust Hemileia coffeicola is restricted to Central and Western Africa especially the higher and cooler coffee regions. 
Table 2. Clones of coffee leaf rust differential hosts for Hemileia vastatrix

\begin{tabular}{llcc}
\hline Code & Coffee designation & Group of resistance & Gene(s) of resistance \\
\hline $849 / 1$ & Matari & $\mathrm{B}$ & Un known \\
$128 / 2$ & Dilla and Alghe & $\alpha$ & $\mathrm{S}_{\mathrm{H}} 1$ \\
$110 / 5$ & S4 Agaro & $\mathrm{J}$ & $\mathrm{S}_{\mathrm{H}} 4,5$ \\
$63 / 1 \mathrm{x}$ & Bourbon & $\mathrm{E}$ & $\mathrm{S}_{\mathrm{H}} 5$ \\
$1343 / 269$ & Hibrido de Timor & $\mathrm{R}$ & $\mathrm{S}_{\mathrm{H}} 6$ \\
$32 / 1$ & DK $1 / 6$ & $\mathrm{D}$ & $\mathrm{S}_{\mathrm{H}} 2,5$ \\
$33 / 1$ & S. $288-23$ & $\mathrm{G}$ & $\mathrm{S}_{\mathrm{H}} 3,5$ \\
$644 / 18$ & Kawasari Hybrid & 3 & $\mathrm{Un} \mathrm{known}$ \\
H.419/20 & MN 1535/33 x HW 26/13 & 2 & $\mathrm{~S}_{\mathrm{H}} 5,6,9$ \\
H.420/2 & & $\mathrm{I}$ & $\mathrm{S}_{\mathrm{H}} 5, \mathrm{~S}_{\mathrm{H}} 8$ \\
H. $420 / 10$ & MN 1535/33 x HW 26/14 & $\mathrm{a}$ & $\mathrm{S}_{\mathrm{H}} 5,6,7,9$ \\
$7962 / 164$ & Catimor Hw26/5 (F6) & $\mathrm{P}$ & $\mathrm{S}_{\mathrm{H}} 5,7$ or $\mathrm{S}_{\mathrm{H}} 5,7,9$ \\
$681 / 7$ & C. canephora Uganda & $\mathrm{N}$ & Un known \\
$168 / 12$ & C. excelsa Longkoi & $\mathrm{K}$ & Un known \\
$829 / 1$ & C. canephora Uganda & $\mathrm{F}$ & Un known \\
13969 & C. racemosa & $\mathrm{Q}$ & Un known \\
$1621 / 13$ & C. congensis Uganda & $\mathrm{B}$ & Un known \\
$263 / 1$ & C. congensis Uganda & & Un known \\
\hline
\end{tabular}

\subsection{Identification of Coffee Leaf Rust Pathogen Races}

Field sampling of coffee leaf of genotype N39 infected with Hemileia vastatrix (coffee genotype N39 is known to be attacked with available possible CLR pathogen races in specific area) was done in 2010 and 2011. The infected leaves were dried while pressed between newspapers, in this way rust lesions would be kept afresh. The uredospores from the lesions were then scraped into conical flask contained sterilized $\mathrm{dH}_{2} \mathrm{O}$. In the solution a drop of tween 80 was added to allow uniform dispersion of uredospores. The uredospores concentration was calibrated at $1 \times 10^{6} / \mathrm{ml}$. Inoculation was done by dipping camels brush into uredospores concentration then rub on the underside of twelve (12) leaves of each of the 18 CLR differentials (Eskes, 1982). The inoculated leaves of the CLR differentials were placed in a labeled plastic box of $30 \mathrm{~cm}$ length $\mathrm{x} 15 \mathrm{~cm}$ width $\mathrm{x} 10 \mathrm{~cm}$ height, covered with black polythene. Dark conditions stimulate formation of the germ tube and subsequently followed by appressorium, which in turn, initiate of the infection process. Two un-inoculated healthy leaves were included as control. Reactions were recorded 40 days after inoculation. Information on the available coffee leaf rust races were determined according to Rodrigues et al. (1975) and Varzea and Marques (2005). They collected samples of the coffee leaves infected by $H$. vastatrix from different coffee growing areas, and then artificially inoculated the leaves of the coffee rust differentials to establish physiological rust races.

\subsection{Variation in Pathogenicity of Colletotrichum kahawae Isolates to Compact Genotypes}

Four (4) Colletotrichum kahawae strains [2006/14 (Kibosho-Kombo Moshi), 2010/2 (Lunji Mbeya), 2010/1 (Kigoma), and 2006/21 (Mbinga)] were used to test the pathogenicity of the compact coffee genotypes. Purity of the strains was done by single spore isolation. $\mathrm{F}_{1}$ hybrid seed produced through artificial pollination between male parents (listed in Appendix 1) and selected compact coffee lines Ctr086, Ctr088 and Ctr127 each year in the seed garden were used as a host in determining the pathogenicity of the $C$. kahawae strains. $\mathrm{F}_{1}$ of each of the 16 hybrids represented by 40 hypocotyls were raised in a plastic box at a spacing of $5 \mathrm{~cm}$ x $5 \mathrm{~cm}$ containing sterilized sand. The experiment was arranged in the laboratory in a completely randomized design (CRD) with three replications. Hypocotyls at 5 to 6 weeks old or 5 to $6 \mathrm{~cm}$ tall were sprayed and inoculated with suspension of C. kahawae strains at a concentration of $2.0 \times 10^{6}$ spores $/ \mathrm{ml}$ twice at $48 \mathrm{hr}$ intervals using a method described by van der Vossen et al. (1976). The inoculum was prepared from 17-23 old days colonies of the four $C$. kahawae strains grown in $3.4 \%$ malt extract agar containing $0.04 \%$ streptomycin. Conidia were dislodged by 
pipetting 4-6 $\mathrm{ml}$ of distilled water onto cultures and then rubbing gently the surface of the mycelia mat with a spatula. The suspension was filtered and the concentration calibrated using haemocytometer to obtain the spore concentration of $2.0 \times 10^{6}$ spores $/ \mathrm{ml}$. Three weeks after the date of first inoculation, coffee seedlings were individually scored for CBD symptoms developed on the hypocotyls using a rating scale from 0 to 4 developed by van der Graff (1982), where 0 is nil and 4 intense CBD infections.

For each genotype disease intensity reaction (DIR) for sixteen $F_{1}$ hybrids was determined to define the pathogenicity as follows:

$$
D I R=25 \frac{\sum i \times n i}{i n}
$$

where, $\mathrm{i}$ is the disease class, $n i$ is the number of seedlings in class $\mathrm{i}$ and $\mathrm{n}$ is the total number of seedlings scored. In determining the DIR of a coffee genotype it requires: assessing the symptoms developed on the hypocotyls using the scale of $0-4$, determining the number of hypocotyls infected per each rating scale, followed by determining the percent infection for each rating scale which then is multiplied by susceptibility of coefficient (0-4). Summation of the products is divided by 4 categories of resistance: Resistance, 0-25; Moderately Resistance, 26-50; Moderately Susceptible; and Susceptible, 76-100).

The level of pathogenicity of the four C. kahawae strains was determined on hypocotyls and green berries of N39, a susceptible variety at an expansion stage. Means of DIR were separated using Tukey's separation test. Data for CBD and CLR were not transformed as the raw data were symmetrically distributed; between the 16 compact coffee genotypes and N39. The data was subjected to analysis of variance (ANOVA) using Genstat software and effects declared significant at 5\% level.

\section{Results}

\subsection{Identification of Hemileia vastatrix Races}

The results on the reaction of rust races on leaves of differentials are as indicated in Table 3 and Figure 2. Differentials 849/1, 63/1x, 32/1, H 420/2, and 1396 had the highest frequency of rust reaction. In this study, the identified coffee rust races are presented in Table 5 whereby seven new coffee rust races were recorded. The new coffee leaf rust races were: XLII, XLI, XXX, XXXVIII, XV, XXXIV, and XXXIX (Table 4).
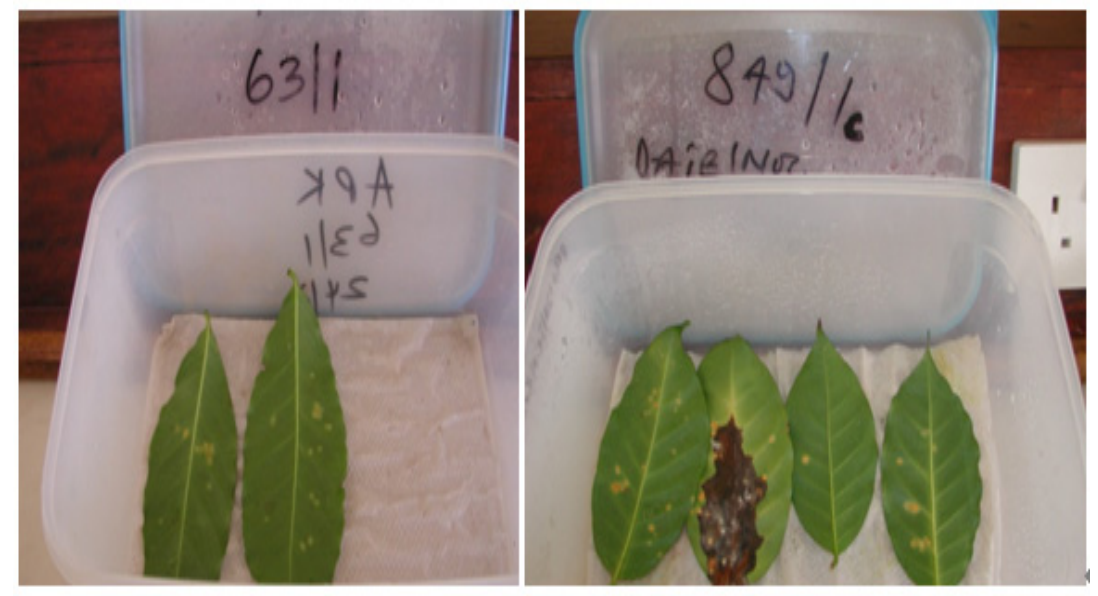

Figure 2. Reaction of rust isolates collected from coffee regions on differentials to detect available races 
Table 3. Reaction of coffee rust differentials to isolates of Hemileia vastatrix in specific areas

\begin{tabular}{|c|c|c|c|c|c|c|c|c|c|c|c|c|c|c|c|c|c|c|c|c|}
\hline \multirow[t]{2}{*}{ S. } & \multirow[t]{2}{*}{ Differential } & \multirow[t]{2}{*}{ Designation } & \multicolumn{18}{|c|}{ Rust reaction on differentials collected from different places } \\
\hline & & & $\begin{array}{l}\vec{\Xi} \\
\vec{\Xi} \\
\tilde{\Xi}\end{array}$ & 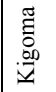 & $\sum_{\substack{\pi \\
\Sigma}}^{\pi}$ & $\begin{array}{l}\tilde{0} \\
\frac{0}{0} \\
\stackrel{0}{7} \\
0\end{array}$ & $\frac{\vec{z}}{\vec{z}}$ & $\begin{array}{l}\text { 咅 } \\
\text { 壳 }\end{array}$ & 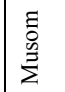 & 竘 & $\begin{array}{l}\text { है } \\
\text { है }\end{array}$ & 莣 & 志 & 亲 & $\begin{array}{l}\text { 夆 } \\
\text { bo } \\
\bar{z}\end{array}$ & 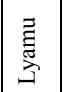 & $\frac{v}{2}$ & 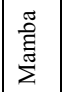 & $\frac{\frac{\pi}{\pi}}{\frac{\pi}{3}}$ & $\begin{array}{l}\stackrel{8}{\Xi} \\
\stackrel{\Xi}{\simeq}\end{array}$ \\
\hline \multicolumn{3}{|c|}{ Altitude (m. a.s.1.) } & 1520 & 1500 & 1510 & 1530 & 1530 & 1530 & 1450 & 1600 & 1650 & 1670 & 1230 & 1320 & 1670 & 1268 & 1100 & 1400 & 1500 & 1600 \\
\hline \multicolumn{3}{|c|}{ Coffee Zone } & \multicolumn{3}{|c|}{ Arabica } & \multicolumn{2}{|c|}{ Robusta } & Arab & \multicolumn{2}{|c|}{ Arab/Robust } & \multicolumn{10}{|c|}{ Arabica } \\
\hline 1 & $849 / 1$ & Matari & $\mathrm{v}$ & $\mathrm{v}$ & $\mathrm{v}$ & $\mathrm{v}$ & $\mathrm{v}$ & & $\mathrm{v}$ & $\mathrm{v}$ & $\mathrm{v}$ & $\mathrm{v}$ & & $\mathrm{v}$ & $\mathrm{v}$ & $\mathrm{v}$ & $\mathrm{v}$ & & $\mathrm{v}$ & \\
\hline 2 & $128 / 2$ & Dilla \& Alghe & & $\mathrm{v}$ & & & & & & & & & & & & & & $\mathrm{v}$ & & \\
\hline 3 & $110 / 5$ & S. 4 Agaro & & & & & & & & & & $\mathrm{v}$ & $\mathrm{v}$ & & & & $\mathrm{v}$ & $\mathrm{v}$ & & \\
\hline 4 & $63 / 1 x$ & Bourbon & $\mathrm{v}$ & $\mathrm{v}$ & $\mathrm{v}$ & $\mathrm{v}$ & & $\mathrm{v}$ & $\mathrm{v}$ & $\mathrm{v}$ & $\mathrm{v}$ & & & $\mathrm{v}$ & $\mathrm{v}$ & $\mathrm{v}$ & $\mathrm{v}$ & $\mathrm{v}$ & $\mathrm{v}$ & $\mathrm{v}$ \\
\hline 5 & $1343 / 269$ & Hibrido de Timor & & & & $\mathrm{v}$ & & & & & & $\mathrm{v}$ & & & & & & & & \\
\hline 6 & $32 / 1$ & DK $1 / 6$ & $\mathrm{v}$ & $\mathrm{v}$ & $\mathrm{v}$ & $\mathrm{v}$ & $\mathrm{v}$ & $\mathrm{v}$ & & $\mathrm{v}$ & & $\mathrm{v}$ & & $\mathrm{v}$ & $\mathrm{v}$ & $\mathrm{v}$ & $\mathrm{v}$ & $\mathrm{v}$ & $\mathrm{v}$ & $\mathrm{v}$ \\
\hline 7 & $33 / 1$ & S. $288-23$ & & & & & & & & $\mathrm{v}$ & & & & & & & & & & $\mathrm{v}$ \\
\hline 8 & $644 / 18$ & H. Kawasari & & & & & & & & & & & & & & & & & & \\
\hline 9 & H.419/20 & 1535/33 Mundo* & & & & & & & & & & & & & $\mathrm{v}$ & & & & & \\
\hline 10 & H.420/2 & 1535/33 Mundo+ & $\mathrm{v}$ & $\mathrm{v}$ & $\mathrm{v}$ & $\mathrm{v}$ & $\mathrm{v}$ & $\mathrm{v}$ & $\mathrm{v}$ & $\mathrm{v}$ & & & & & & & $\mathrm{v}$ & & & \\
\hline 11 & H. $420 / 10$ & 1535/33 Mundo+ & & & & & & & & & & & & & & & $\mathrm{v}$ & & & \\
\hline 12 & $7962 / 164$ & Catimor HW 26/546 & $\mathrm{v}$ & $\mathrm{v}$ & & $\mathrm{v}$ & & $\mathrm{v}$ & & & $\mathrm{v}$ & & & & & $\mathrm{v}$ & & & $\mathrm{v}$ & $\mathrm{v}$ \\
\hline 13 & $681 / 7$ & C. canephora Ug & & & & & & & & & & & & & & & & & & \\
\hline 14 & $168 / 12$ & C. excels Longkoi & & $\mathrm{v}$ & $\mathrm{v}$ & $\mathrm{v}$ & $\mathrm{v}$ & $\mathrm{v}$ & & $\mathrm{v}$ & & & & & $\mathrm{v}$ & & $\mathrm{v}$ & & $\mathrm{v}$ & \\
\hline 15 & $829 / 1$ & C. canephora Ug & & & & & & & & & & & & & & & & & & \\
\hline 16 & $1621 / 13$ & C. congensis $U g$ & & & & & & & & & & & & & & & & & & \\
\hline 17 & $263 / 1$ & C. congensis $U g$ & & & & & & & & & & & & & & $\mathrm{v}$ & & $\mathrm{v}$ & & \\
\hline 18 & 1396 & C. racemosa & $\mathrm{v}$ & $\mathrm{v}$ & $\mathrm{v}$ & $\mathrm{v}$ & $\mathrm{v}$ & $\mathrm{v}$ & $\mathrm{v}$ & $\mathrm{v}$ & & & & & & & $\mathrm{v}$ & & & \\
\hline
\end{tabular}

Key: * Mundo Novo x HW 26/13, + Mundo Novo x HW 26/14, v = Rust infection on leaves of differentials, Arab $=$ Arabica, Robust $=$ Robusta.

Table 4. Characterization of physiologic coffee rust races of Hemileia vastatrix existing in Tanzania

\begin{tabular}{|c|c|c|c|c|}
\hline Location & Altitude (m a.s.l) & Race & Remarks & Virulence gene \\
\hline Kasulu & 1520 & XLII & New race & $\mathrm{v} 2,5,7,8$ or $\mathrm{v} 2,5,7,8,9$ \\
\hline Kigoma & 1500 & New race* & Needs confirmation & $\mathrm{v} 1,2,5,7,8$ or v1, $2,5,7,8,9$ \\
\hline Mwayaya & 1510 & XLI & New race & $v 2,5,8$ \\
\hline Bukoba & 1330 & New race* & Needs confirmation & v $2,5,6,7,8$ or v $2,5,6,7,8,9$ \\
\hline Maruku & 1354 & XLI & New race & $\mathrm{v} 2,5,8$ \\
\hline Maruku-KP423 & 1354 & XLII & New race & $\mathrm{v} 2,5,7,8$ or $\mathrm{v} 2,5,7,8,9$ \\
\hline Musoma & 1450 & XXX & New race & v5, 8 \\
\hline Tarime & 1600 & New race* & Needs confirmation & $\mathrm{v} 2,3,5,8$ \\
\hline Mbimba & 1650 & XXXIII & New race & $v 5,7$ oor v5, 7,9 \\
\hline Shiwanda & 1670 & XXVIII & Known race & $v 2,4,5,6$ \\
\hline Utiri & 1230 & XV & New race & $\mathrm{v} 4,5$ \\
\hline Burka & 1320 & I & Known race & $\mathrm{v} 2,5$ \\
\hline Ng'uni & 1670 & XXXI & Known race & $v 2,5,6,9$ \\
\hline Lyamungu & 1268 & XXXIV & New race & $\mathrm{v} 2,5,7$ or $\mathrm{v} 2,5,7,9$ \\
\hline APK & 1100 & XXXIX & New race & $v 2,4,5,6,7,8,9$ \\
\hline Mamba & 1400 & I & Known race & $\mathrm{v} 1, ?, 2,4, ?, 5$ \\
\hline Mokala & 1500 & XXXIV & New race & $\mathrm{v} 2,5,7$ or $\mathrm{v} 2,5,7,9$ \\
\hline Rombo & 1600 & New race* & Needs confirmation & $\mathrm{v} 2,3,5,7$ or $\mathrm{v} 2,3,5,7,9$ \\
\hline
\end{tabular}

NB: * Further research work required to establish a type of the race. 


\subsection{Variation in Pathogenicity of Colletotrichum kahawae Isolates to Compact Coffee Genotypes}

The results in Table 5 show the pathogenicity of $C$. kahawae strains on hypocotyls of the compact coffee genotypes. There was a significant $(\mathrm{P}<0.05)$ variation in the pathogenicity of Colletotrichum kahawae strains to compact coffee genotypes. The four $C$. kahawae strains were less pathogenic to the coffee genotypes CVT2 (Ctr088 x (SL34 x HdT) x Kent x Rume Sudan), CVT4 (Ctr088 x (SL34 x HdT) x Rume Sudan), CVT5 (Ctr 088 x (Rume Sudan x Catuai), CVT7 (Ctr088 x (HdT x N39) x SL28) x (N39 x Rume Sudan), CVT8 (Ctr088 x (N39 x HdT) x (N39 x HdT) x Rume Sudan) and CVT13 (Ctr127 x (Blue Mountain Jamaica x Cioccie) x Rume Sudan). The pathogenic level of the four C. kahawae strains was highly expressed to the check variety N39; $(\mathrm{DIR}=100)$, compared to Ctr088 a pure line of compact coffee genotype with zero score of DIR (Table 5).

Table 5. Disease Intensity Reaction (DIR) of the four C. kahawae strains on coffee genotypes

\begin{tabular}{|c|c|c|c|c|}
\hline \multirow{2}{*}{ Coffee Genotype } & \multicolumn{4}{|c|}{ DIR of C. kahawae strains } \\
\hline & $2006 / 14$ & $2010 / 2$ & $2010 / 1$ & $2006 / 21$ \\
\hline CVT1 & $6.75^{\mathrm{g}}$ & $20.0^{\mathrm{bc}}$ & $6.25^{\mathrm{b}}$ & $32.9^{\mathrm{bc}}$ \\
\hline CVT2 & $22.5^{\mathrm{efg}}$ & $13.75^{\mathrm{bc}}$ & $7.5^{\mathrm{b}}$ & $17.5^{\text {bcde }}$ \\
\hline CVT3 & $37.5^{\text {cdefg }}$ & $4.5^{\mathrm{bc}}$ & $6.25^{\mathrm{b}}$ & $2.5^{\mathrm{de}}$ \\
\hline CVT4 & $17.5^{\mathrm{efg}}$ & $7.3^{\mathrm{bc}}$ & $0.0^{\mathrm{b}}$ & $4.4^{\text {cde }}$ \\
\hline CVT5 & $15.0^{\mathrm{efg}}$ & $6.25^{\mathrm{bc}}$ & $0.0^{\mathrm{b}}$ & $11.65^{\text {bcde }}$ \\
\hline CVT6 & $28.85^{\text {defg }}$ & $20.0^{\mathrm{bc}}$ & $28.75^{\mathrm{b}}$ & $23.75^{\text {bcde }}$ \\
\hline CVT7 & $9.5^{\mathrm{g}}$ & $0.7^{\mathrm{c}}$ & $17.5^{\mathrm{b}}$ & $16.3^{\text {bcde }}$ \\
\hline CVT8 & $11.3^{\mathrm{fg}}$ & $10.3^{\mathrm{bc}}$ & $21.3^{\mathrm{b}}$ & $8.8^{\text {bcde }}$ \\
\hline CVT9 & $48.8^{\text {bcdef }}$ & $10.0^{\mathrm{bc}}$ & $3.8^{\mathrm{b}}$ & $28.5^{\text {bcde }}$ \\
\hline CVT10 & $71.3^{\mathrm{abc}}$ & $23.7^{\mathrm{bc}}$ & $8.8^{\mathrm{b}}$ & $34.8^{\mathrm{b}}$ \\
\hline CVT11 & $66.0^{\mathrm{abcd}}$ & $32.9^{\mathrm{b}}$ & $12.5^{\mathrm{b}}$ & $31.7^{\mathrm{bcd}}$ \\
\hline CVT12 & $87.8^{\mathrm{ab}}$ & $24.7^{\mathrm{bc}}$ & $24.9^{\mathrm{b}}$ & $33.6^{\mathrm{bc}}$ \\
\hline CVT13 & $20.0^{\mathrm{efg}}$ & $9.7^{\mathrm{bc}}$ & $6.3^{\mathrm{b}}$ & $12.9^{\text {bcde }}$ \\
\hline CVT14 & $52.5^{\text {bcde }}$ & $18.8^{\mathrm{bc}}$ & $27.5^{\mathrm{b}}$ & $14.2^{\text {bcde }}$ \\
\hline CVT15 & $65.0_{\mathrm{abcd}}$ & $13.8^{\mathrm{bc}}$ & $13.8^{\mathrm{b}}$ & $22.6^{\text {bcde }}$ \\
\hline CVT16 & $48.8^{\text {bcdef }}$ & $26.1^{\mathrm{bc}}$ & $27.5^{\mathrm{b}}$ & $10.5^{\text {bcde }}$ \\
\hline PNI 088 & $0^{\mathrm{g}}$ & $0^{\mathrm{c}}$ & $0^{\mathrm{b}}$ & $0^{\mathrm{e}}$ \\
\hline N39 & $100^{\mathrm{a}}$ & $100^{\mathrm{a}}$ & $100^{\mathrm{a}}$ & $100^{\mathrm{a}}$ \\
\hline Mean & 39.4 & 19 & 17.4 & 22.6 \\
\hline Tukey’s significant difference $(0.05)$ & 6.8 & 5.0 & 5.2 & 5.1 \\
\hline Variance & 838.4 & 464.9 & 494.7 & 467.8 \\
\hline
\end{tabular}

Key: DIR 0-25, Resistant, 26-50, Moderately Resistant; 51-75 Moderately Susceptible and 76-100 Susceptible Means followed by a common letter within a column do not differ significantly according to Tukey's ( $\mathrm{P} \leqslant$ $0.05)$. 


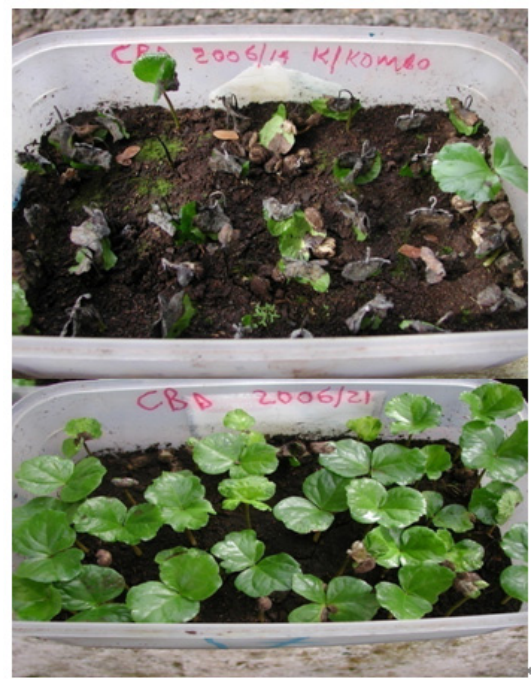

Figure 3. Pathogenic effect of CBD strain 2006/14 (Top) and 2006/21 (Bottom) artificially inoculated same day

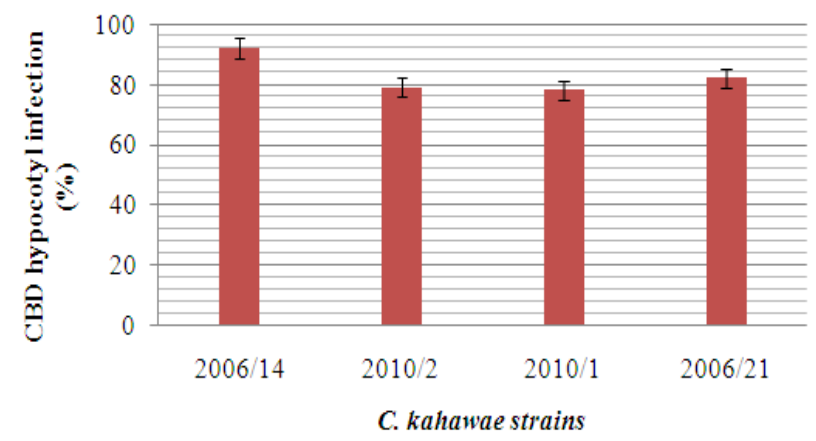

Figure 4. Percentage CBD infection on hypocotyls of coffee genotype N39

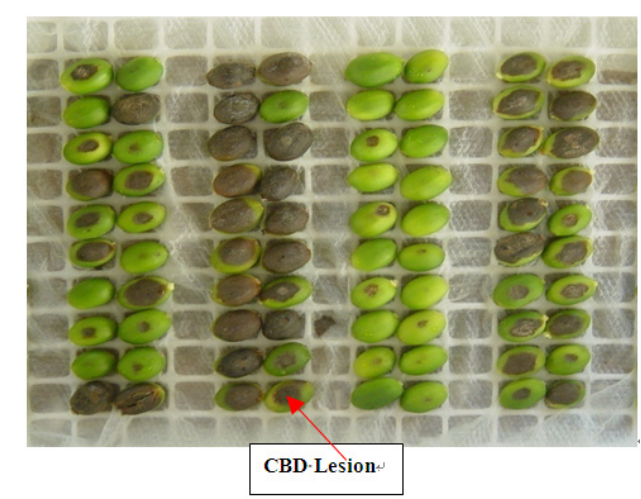

Figure 5. Lesions as the result of pathogenicity of C. kahawae strains on green berries of N39 from left to right; 2010/2, 2006/14, 2010/1 and 2006/21

\subsection{Variation in Pathogenicity of Colletotrichum kahawae Strains to Hypocotyls of N39}

Figures 3 and 4 present the results of the four $C$. kahawae strains to hypocotyls of susceptible coffee genotypes N39. With a score of $92 \%$ CBD infection on hypocotyls of N39, C. kahawae strain 2006/14 was more pathogenic than strains 2010/2, 2010/1 and 2006/21 with the percentage CBD infection on hypocotyls which range from $78 \%$ to $82 \%$. 
The levels of pathogenicity of the four C. kahawae strains were determined on green berries of N39 at an expansion stage. The differences of the lesions were as shown in Figure 5. Green berries infected with $C$. kahawae strain 2006/14 had wider black lesions of 4-5 mm than the rest of the strains with 1-3 $\mathrm{mm}$ recorded seven days after artificial inoculation (Figure 5).

\section{Discussion}

Updating of information of available coffee rust races forms an important activity in producing coffee varieties with durable resistance to Hemileia vastatrix. In Tanzania the first information on the existence of coffee leaf rust races was done in 1975. Rodrigues et al. (1975) reported the existence of seven rust races collected in different coffee growing ecosystems in Tanzania. The races recorded included race I, II, III, XVII, XXIV, XI, and $X X$. This information was updated 22 years later whereby CIFC (2007) recorded the existence of two new rust races XXXIV and XXII, and in 2009 races XXIII, XXIV, XXV, XXVIII and XXVI (TaCRI, 2009). In this study seven new races have been identified within a period of two years; 2010 and 2011. The coffee leaf rust races identified were; XLII, XLI, XXX, XXXIII, XV, XXXIV, and XXXIX. This information is very useful in formulating strong breeding programmes. Van der Vossen (2005) reported that resistance genes $\mathrm{S}_{\mathrm{H}} \mathrm{I}-\mathrm{S}_{\mathrm{H}} 9$ have all been successively defeated in C. arabica by emerging new physiologic races of the CLR pathogen $H$. vastatrix in some coffee growing areas in the world. It is reported that mutation is the likely mechanism for new race formation as no alternative host to H. vastatrix has been found (Varzea \& Marques, 2005). Catimors including genotypes Ctr086, PNI088 and Ctr127 still provides full resistance to all types of coffee rust races (Van der Vossen, 2005). As these races were identified from areas where the 16 compact genotypes were exposed, implies that there are genotypes with complete resistance to CLR.

The results on DIR of C. kahawae strains found on coffee genotypes CVT2, CVT4, CVT5, CVT7, CVT8 and CVT13; showed that there were potential compact genotypes with high levels of resistance to CBD. These can be used to improve coffee breeding programme in Tanzania. Some of these genotypes like CVT2 were found to produce economical yields and cup taste classified for export value. Colletotrichum kahawae strain 2006/14 showed a high level of pathogenicity. The strain demonstrated to be pathogenic on hypocotyls and green berries of N39. Studies done by Kilambo (2008) identified this strain as one of the most aggressive C. kahawae strains in the country. The bio-chemical analysis using iso-enzymes applied to 25 C. kahawae strains collected from coffee growing areas in Tanzania confirmed that strain 2006/14 formed a peculiar identity compared to other strains (Kilambo et al., 2008). The findings confirm that this strain can be used to screen for genotypes with resistance to CBD. High levels of CBD shown by Ctr088 confirms studies done by Gichuru et al. (2008) when studying the $\mathrm{F}_{2}$ populations of Ctr088 x SL28 to map the Ck-1 gene by molecular markers. The genotype can be used as a donor parent for genes of CBD resistance to breed coffee varieties with resistance to C. kahawae.

In the light with the occurrence on variability of $H$. vastatrx and C. kahawae strains in Tanzania, TaCRI will quite often be faced with the challenges of finding the information on the CLR and CBD populations and their evolution. This will assist in improving coffee genotypes found to have good agronomic characteristics which have also high spectra of resistance. Recently, additional physiological races of $H$. vastatrix were identified in Kenya (Gichimu et al., 2012) revealling a challenge to coffee breeding programme in this region. That is why currently TaCRI is not only involving HdTs; natural hybrids between C. arabica and C. canephora which have genes responsible for rust resistance (Diniz et al., 2012), but catimors also confirmed to be resistant to local races existing in Tanzania. It is therefore important that while studying host resistance, parallel studies of pathogen variability in relation to disease resistance should also be made.

\section{Conclusion}

Coffee leaf rust disease (Hemileia vastatrix) and coffee berry disease (Colletotrichum kahawae) are in Tanzania the most important disease in Arabica coffee (Coffea arabica). They cause annually considerable economic damage due to crop losses, as most of Arabica coffee is still produced on susceptible cultivars. There is an urgent need for improving the levels of resistance to CLR and CBD in Arabica coffee, by exploiting resistant genes from Catimor genotypes like Ctr086, Ctr088 and Ctr127 in breeding programmes. The Catimor genotypes crossed to known hybrids with good agronomic attributes may assist in recommending the best commercial coffee genotypes with resistance to CLR and CBD. In the light of breakdown of resistance due to emerging of new physiologic disease strains, studies of pathogen variability in relation to disease resistance should also be made.

\section{Acknowledgements}

Authors wish to acknowledge Mrs. Josephine Urassa for collection and preparation of the leaves and coffee berry samples, Dr. Vitor Varzea of CIFC Oeiras Porugal to assist in identification of rust races and Dr. Hubert 
van der Vossen for commenting on a draft of this paper. The Government of Tanzania through Tanzania Commission for Science and Technology (COSTECH) for the funding support of the study.

\section{References}

CIFC. (2007). Scientific Collaboration in Fundamental and Practical Knowledge in the two Most Important Coffee Diseases in Tanzania (CLR and CBD) with the Ultimate Aim of Producing Varieties with Durable Resistance to these Pathogens. Project Number: TA STA COF 99 01.Oeiras, Portugal. p.6

Diniz, I., Tahhinhas, P., Azinheira, H. G., Varzéa, V., Medeira, C., Maia, I., ... Silva, M. C. (2012). Cellular and molecular analysis of coffee resistant to Hemileia vastatrix and non-host resistance to Uromyces vignae in the resistance-donor genotype HdT 832/2. European Journal of Plant Pathology, 133, 141-157. http://dx.doi.org/10.1007/s10658-011-9925-9

Eskes, A. B. (1982). The use of leaf disc inoculations in assessing resistance to coffee leaf rust (Hemileia vastatrix). Netherlands Journal of Plant Pathology, 88, 127-141. http://dx.doi.org/10.1007/BF01977270

Flor, H. H. (1971). Current status of the gene-to-gene concept. Annals Review of Phytopathology, 9, 275-296. http://dx.doi.org/10.1146/annurev.py.09.090171.001423

Gichuru, E. K., Agwanda, C. O., Combes, M. C., Mutitu, E. W., Ngugi, E. C. K., Bertrand, B., \& Lashermes, Ph. (2008). Identification of molecular markers linked to a gene conferring resistance to coffee berry disease (Colletotrichum kahawae) in Coffea Arabica L. Plant Pathology, 57, 1117-1124. http://dx.doi.org/10.1111/j.1365-3059.2008.01846.x

Gichuru, E. K., Ithiru, J. M., Silva, M. C., Pereira, A. P., \& Varzéa, V. M. P. (2012). Additional physiological races of coffee leaf rust (Hemileia vastatrix) identified in Kenya. Tropical Plant Pathology, 37(6), 424-427. http://dx.doi.org/10.1590/S1982-56762012000600008

Kilambo, D. L., Guerra-Guimarães, L., Várzea, V. M. P., Loureiro, A., Silva, M., Mabagala, R. B., ... Teri, J. M. (2008). Pathogenicity of Colletotrichum kahawae strains and their effect on resistant Arabica coffee varieties in Tanzania. Retrieved from http://www.asic-conferene.org

Kilambo, D. L. (2008). Virulence of Colletotrichum kahawae strains and their effect on resistant Arabica coffee varieties in Tanzania. Dissertation for Award of MSc Degree at Sokoine University of Agriculture, Morogoro, Tanzania, p. 116.

Rodrigues Jr. C. J., Betterncort, A. J., \& Rijo, L. (1975). Races of the pathogen and resistance to coffee rust. Annual Review of Phytopathology, 13, 49-70. http://dx.doi.org/10.1146/annurev.py.13.090175.000405

Rodrigues, Jr. C. J., Varzea, V. M., \& Medeirol, E. F. (1992). Evidence for the existence of physiological race of Colletotrichum coffeanum Noack. Kenya Coffee, 672, 1417-1420.

Tanzania Coffee Research Institute (TaCRI). (2009). Annual Report for 2009 (p. 23). Tanzania Coffee Research Institute. Lyamungu, Moshi, Tanzania.

Van der Graaff, N. A. (1982). The principles of scaling and the inheritance of resistance to coffee berry disease in Coffea Arabica. Euphytica, 31, 735-740. http://dx.doi.org/10.1007/BF00039212

Van der Vossen, H. A. M. (2005). State of the art of developing durable resistance to biotrophic pathogens in crop plants, such as coffee leaf rust. In E. Zambolim, M. Zambolim \& V. M. P. Varzea (Eds.), Resistance to Coffee Leaf Rust (p. 305) Brazil: Vicosa.

Van der Vossen, H. A. M., Cook, R. T. A., \& Murakaru, G. N. W. (1976). Breeding for the resistance to coffee berry disease caused by Colletotrichum coffeanum in Coffea arabica L. I. Methods of preselection for resistance. Euphytica, 25, 733-745. http://dx.doi.org/10.1007/BF00041613

Varzea, V. M. P., \& Marques, D. V. (2005). Population variability of Hemileia vastatrix Against Durable Resistance. In E. Zambolim, M. Zambolim \& V. M. P. Varzea (Eds.), Durable Resistance to Coffee Leaf Rust, (p. 305) Brazil: Vicosa.

Waller, J. M., Bridge, P. D., Black, R., \& Hakiza, G. (1993). Characterization of the coffee berry disease pathogen, Colletotrichum kahawae Sp. Nov. Mycological Research, 97, 989-994. http://dx.doi.org/10.1016/S0953-7562(09)80867-8 
Appendix 1. Coffee genotypes of compact coffee breeding lines

\begin{tabular}{ll}
\hline Code no & Genotype \\
\hline CVT1 & Ctr088 x (N39 x Rume Sudan Selfed F $)$ \\
CVT2 & Ctr088 x (SL34 x HdT) x Kent x Rume Sudan \\
CVT3 & Ctr088 x (Padang x (HdT x N39) x Rume Sudan \\
CVT4 & Ctr088 x (SL34 x HdT) x Rume Sudan \\
CVT5 & Ctr088 x (Rume Sudan x Catuai) \\
CVT6 & Ctr088 x (Blue Mountain Jamaica x Cioccie x HdT x Rume Sudan) \\
CVT7 & Ctr088 x (HdT x N39) x SL28) x (N39 x Rume Sudan) \\
CVT8 & Ctr088 x (N39 x HdT) x (N39 x HdT) x Rume Sudan \\
CVT9 & Ctr127 x (Rume Sudan x Catuai) \\
CVT10 & Ctr127 x (N39 x Rume Sudan Selfed F $)$ \\
CVT11 & Ctr127 x (N39 x HdT) x HdT \\
CVT12 & Ctr127 x (Padang x (HdT x N39) x Rume Sudan \\
CVT13 & Ctr127 x (Blue Mountain Jamaica x Cioccie) x Rume Sudan \\
CVT14 & Ctr086 x (N39 x Rume Sudan Selfed F $)$ \\
CVT15 & Ctr086 x (Rume Sudan x Catuai) \\
CVT16 & Ctr086 x (N39 x Rume Sudan Selfed F 2$)$ \\
SC9 & (N39 x OP729) x HdT) x N39 (SC9) \\
SC13 & Kent Hb x HdT (SC13) \\
Ctr088 & Catimor Ctr088 \\
N39 & N39 \\
\hline
\end{tabular}

\section{Copyrights}

Copyright for this article is retained by the author(s), with first publication rights granted to the journal.

This is an open-access article distributed under the terms and conditions of the Creative Commons Attribution license (http://creativecommons.org/licenses/by/3.0/). 